\title{
Conceptual Roots And Synergistic Communalities In Economics And Marketing
}

Abram Poczter, New York Institute of Technology, USA

Sharon L. Poczter, University of California, Berkeley, USA

\begin{abstract}
Marketing as a scientific discipline has a very long practice but relatively brief history, as opposed to Economics, crowned as the queen of social sciences in antiquity. Both disciplines share an interest in consumer behavior, on both micro and micro levels. However, taught at different schools and departments of universities, these disciplines developed own methodologies and research approaches, foregoing obvious synergies. This paper discusses several concepts and theories developed in one of the disciplines that ought to be taught in the other.
\end{abstract}

Keywords: Interdisciplinary, marketing, economics, leisure class, microeconomics, conjoint measurement

\section{INTRODUCTION}

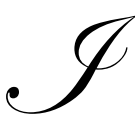

$\mathrm{t}$ is difficult to pinpoint the beginning of the current trend toward interdisciplinary approach to the analysis, interpretation, and search for solutions to the issues of human condition, and in business area in particular. In areas as different as global warming to vagaries of the stock market, to technological conversion, to social networks, pandemics, etc it is de rigueur to put together team of specialists representing relevant and very different disciplines. Individuals, whose college and graduate education emphasized increasing level of specialization (a PhD is someone who knows everything about nothing), need to cross-fertilize with what often is a "terra incognita." Similarly, in most business and economics programs, departments build "silo" around themselves, retarding the process to educating a general manager.

Of course, college and masters level curricula require students to take a variety of courses within the core and majors, but the courses are not taught in a interdisciplinary fashion, except for the "capstone" experience.

The interdisciplinary aspect is typically reflected in team teaching the capstone course, which is, however, is too expensive for most of the less endowed schools.

We would argue that the course syllabi out to reflects the interdisciplinary nature of the field, stimulating faculty and students to adopt the broad perspective in study and research

It will be illustrated, the relevance of economics, sociology, and psychology in marketing, more specifically - consumer behavior.

\section{VERY BRIEF HISTORY OF SOCIAL SCIENCES}

Shortly after the Ancient Greeks named the study of household production and exchange transactions, oikonomia, it has risen to become the "queen of social sciences," attracting such minds as Plato, Aristotle, and Cicero. From those common roots, the tree of knowledge has sprung distinct trunks, branches and leaves. Marketing has a very long past but a very short history of evolution as a separate discipline (mid $20^{\text {th }}$ ), from the "trunk" of agricultural economics. 
In itself, economics has evolved, by concentrating on aggregates of households and firms, referred to as economies. A perfect illustration is the progression of work by Adam Smith, who followed up The Theory of Moral Sentiments (1759) with The Wealth of Nations (1776). Upon adding a political component, economics become Political Economy, which in turn split into Political Science and Economics, the later studying the individuals, households, and firms (Micro) and Economic aggregates such as Consumption, Investment, Savings, etc (Macro). The overwhelming issue became mathematical modeling of the Market Equilibrium, and economics appeared to parade as an applied mathematics, a visible sign of it was the award of 1994 Nobel Memorial Prize in Economic Sciences to John F. Nash, a mathematician.

Meanwhile, aggregating across individuals, necessitated applications of "Occam's razor" to a point that made the economic models into very elegant jewels in a glass case, very elegant, but not very useful for decision making, in either economics or marketing. For example, according to Bergmann (1996), "Becker gives proof that women do better under polygamy than under monogamy because the price they get for selling themselves into marriage under polygamy is higher. His argument is false since in societies that allow polygamy, the status of women is abysmal.

As the financial markets melt-down of October 2008 indicated, the model are outright dangerous when used. Winter stated:

"As computers have grown more powerful, academics have come to rely on mathematical models to figure how various economic forces will interact. But many of those models simply dispense with certain variables that stand in the way of clear conclusions, says Wharton management professor Sidney G. Winter. Commonly missing are hardto-measure factors like human psychology and people's expectations about the future, he notes."

Moreover, treatment of a product as a whole, as possessing use-utility, and the associated concept of "consumer sovereignty," has all but delegitimized marketing activities aimed at attitude development and change, motivation, and brand-switching behavior. The implicit form of the utility function, or the strict rationality assumptions of revealed preferences, circumspect the importance of sociological and psychological impact on consumer behavior, as it was amply demonstrated by the inability of US economic gurus to prevent the devastation caused by the "irrational exuberance."

The rise of so-called Behavioral Economics and Finance is yet another example of "disconnect" between economics and marketing. Instead, of building on the existing theories and empirical body of knowledge, the behavioral economists at best, will reinvent the wheel. Incidentally, 2002 Nobel Memorial Prize in Economic Sciences went to a psychologist, Daniel Kahneman.

\section{TOPICS TO CONSIDER FOR INCLUSION}

The task of marketing academics is to teach and research the economic origin of many a marketing concept. In many cases, economists themselves provide very convenient points of departure. For example:

- $\quad$ Thorsten Veblen (1899) in the Theory of the Leisure Class emphasized the importance of culture and the hierarchical structure of human institutions and society (sociology) in brand choices. Conspicuous consumption, a term coined by Veblen, underlines the imitation and trickle down effects, as well as the symbolic nature of brands, which in turn relates to Freudian and Jungian symbolism (1964).

- James Duesenberry (1949), developed the Relative Income Hypothesis to explain the empirically observed contradiction of a constant Consumption/Income ratio in a long run, and changes of this ratio over the economic cycle. Although, pushed from the limelight by Milton Friedman's Permanent Income Hypothesis, Duesenberry provides, nevertheless, an important input into forecasting consumption levels over an economic cycle. The Relative Income Hypothesis, as a theory, in its construction and the empirical testing, points out to the importance of social dynamics in estimating market potential, given the trend in economic environment, and in forecasting success of new products.

- $\quad$ Kenneth Arrow (1972) in his Nobel Prize lecture called for inclusion of other social science into the study of economic behavior, so economic models do not become "jewel in a glass case." This call is the motivation behind writing this article. 
- $\quad$ Kevin Lancaster (1966) in New Approach to Consumer Theory broke with the orthodoxy in viewing products as a bundle of characteristics satisfying consumer needs:

Lancaster (1966) stated “... simply asking consumers about the characteristics associated with various commodities may be much more productive than attempts to extract information concerning preferences within the context of conventional theory." (p.153)

This theory enriches the Multi-attribute Models widely used in marketing. Moreover, Conjoint Measurement, a key model in new product development, is a perfect combination of the psychological model of attitude (Fishbein), economic utility theory and the Lancaster's view.

It is quite inspiring to see The 2009 Second Conjoint Analysis in Health Conference, organized by the prestigious John Hopkins' Bloomberg School of Medicine

- Gary Becker (1960), in addition to the controversial conclusion on the price mechanism in marriages, in clarifying altruism has anticipated Wikipedia, YouTube, Google Earth and other examples of selfless human behavior, which marketing struggles to fully understand.

\section{CONCLUSION}

In closing, the connection between marketing and economics should lead to increased legitimacy of marketing in the eye of the economists, and an interdisciplinary research, better reflecting the complex nature of consumer and human behavior.

\section{AUTHOR INFORMATION}

Dr. Abram Poczter is a Professor of Marketing and Management with interests in interdisciplinary market theories, management of innovations, customer value and strategic management.

Sharon L. Poczter is a PhD student in Business and Policy Group, with interests in strategy, impact of business cycle on market imperfections, capital structure and productivity of the business enterprises.

\section{REFERENCES}

1. Becker, Gary (1976). The Economic Approach to Human Behavior, Chicago: University of Chicago Press, 1976;

2. Bergmann, Barbara, R. (1996). "Becker's Theory of the Family: Preposterous Conclusions." Challenge (05775132); Jan/Feb96, Vol. 39 Issue 1, p9-12, 4p

3. Duesenberry, James S. (1949). Income, Savings and the Theory of Consumer Behavior. Cambridge: Harvard University Press

4. Jung, Carl (ed). (1964). Man and his symbols. New York: Dell Publishing

5. Lancaster, Kevin (1966). 'A New Approach to Consumer Theory.' Journal of Political Economy. (p.153)

6. Smith, Adam. (1759) The Theory of Moral Sentiments . London: A. Millar

7. Smith, Adam. (1776) An Inquiry into the Nature and Causes of the Wealth of Nations. London: Methuen \& Co., Ltd.

8. Veblen, Thorsten, B. (1899). The Theory of the Leisure Class; an economic study of institutions. London: Macmillan \& Co., LTD

9. Winter, Sidney G. in "Why Economists Failed to Predict the Financial Crisis" (May 13, 2009):

Knowledge@Wharton http://knowledge. wharton.upenn.edu/article.cfm?articleid=2234 
NOTES 